\title{
Does the Pandemic Matter? \\ Diagnosing the Immediate Effects of the Covid-19 Pandemic on the Financial Security of Small Enterprises in Poland
}

\author{
DOMINIKA KORDELA \\ Institute of Economics and Finance \\ University of Szczecin \\ POLAND \\ MONIKA PETTERSEN-SOBCZYK \\ Institute of Spatial Management and Socio-Economic Geography \\ University of Szczecin \\ POLAND
}

\begin{abstract}
The Covid-19 pandemic broke out unexpectedly, and it is difficult to anticipate its future effects. As a result of the lockdowns, many enterprises were forced to curtail their business as early as in the first months of the pandemic. In view of such unprecedented phenomena, a question arises about possible effects of the pandemic on the financial standing of enterprises. The authors of this paper aimed to assess the immediate effects of the Covid-19 pandemic on the financial security of small enterprises in Poland, since the financial security is seen as an important factor influencing organizational resilience. This article applies the desk research and comparative analysis methods, which were conduct based on statistic office data. The studied enterprises were analysed in terms of changes in their liquidity ratios, sales profitability ratios as well as their revenue and profit levels - the results have shown a considerable diversity across sectors. Based on the assessment of changes in the indicators, the analysed sectors were categorised as: resistant sectors, hardly affected sectors, moderately affected sectors, severely affected sectors. The analysis of the selected indicators of financial security has shown that the financial result as well profitability levels were the indicators that deteriorated in the greatest number of sectors. Surprisingly, financial liquidity remained the most stable indicator. The research results can be helpful in proper channelling aid to enterprises to recover from crisis, since in first month of the pandemic most of financial support was not diversified.
\end{abstract}

Key-Words: small enterprises, Covid-19 pandemic, financial standing, financial security, organizational resilience

Received: May 20, 2021. Revised: August 20, 2021. Accepted: August 23, 2021. Published: August 26, 2021.

\section{Introduction}

Taking into consideration external factors, mainly the economic and the financial crisis caused disruptions in enterprises in pre-Covid-19 times. In such a crisis circumstances being resilient help to overcome the downturn. Since 2020 the economy faces the turbulence again, and one can quote Reinhardt and Rogoff "This time is different".

The Covid-19 pandemic, which has been sweeping across Europe since January 2020, was addressed by the Organisation for Economic Co-operation and Development (OECD) as "the most serious economic crisis in a century" [1]. In the EU as well as all over the world, most of administrative, social and economic activities were suspended. The protective measures varied depending on the country, but generally they tended to be radical and involved closing of restaurants, hotels, shops, schools, universities, and workplaces. Despite the short period from the beginning of the pandemic, its course and effects have already been widely described in the economic literature. Some scientists focused on macroeconomic aggregates [2][3][4], others on the situation of business entities and consequences of COVID-19 on business failures [5][6][7]. The latter is more closely related to our approach. Last year quite a lot of research regarding the influence of the pandemic on business was published. The studies focused on logistics blocks, labor shortages, and drops in demand, business risk [8][9], corporate resiliency [10][11], or financial support and subsidies [12][13][14]. To best of our knowledge, there is a shortage of papers on the 
financial standing of small enterprises during the pandemic crisis. The objective of our research was to assess the immediate impact of the COVID-19 pandemic on the financial security of small enterprises, understood as "state of financial resources, which provides effective (profitable) activity of an enterprise, protects its financial interests and maintains its ability to regulate liquidity, solvency and financial capabilities under the influence of various kinds of dangers and threats" [15]. We studied the changes of main indicators of financial security by comparing them to the values in previous periods. The comparative analysis of indicators was engaged hence the financial security is seen as an important factor of the organizational resilience. We aimed to check whether the influence of the pandemic was reflected in financial indicators as early as in the first months of the lockdown, as the problems in organization are signaled by deterioration of financial ratios. No business is immune from an unexpected crisis, nevertheless in our paper we assessed the reaction of main financial indicators in the particular sectors of small enterprises. According to Adian et. al. [16], the vulnerability of SMEs to the crisis depends in part on their prevalence in more crisis-exposed countries and sectors, which justifies the sectoral approach applied in this paper.

The scientific curiosity focused on the way small enterprises cope with turbulent surrounding caused by pandemic inspired the authors of this paper to engage in a study aimed at assessment of immediate effects of the Covid-19 pandemic on the financial security of small enterprises in Poland in the period from January to June 2020. The specific objective was to evaluate the diversity of the immediate effects of the pandemic on the financial security of small enterprises in sectors of the Polish economy. The knowledge about vulnerability on crisis assessed on base of financial indicator in the particular sectors might be useful regarding organizational resilience, since it is understood as well as a function of planning for and preparing for future crisis [17]

The paper is organized as follow: section 2 presents the theoretical underpinning, which presents briefly different views on organizational resilience and on as well on SMEs in crisis. The third section includes research assumption such as the financial indicators used to assess different aspects of financial security of small enterprises, and the steps of the research process and the results of the empirical analysis. Section 4 includes the discussion, where the findings are compared with the results of previous research studies on Covid-19 and financial standing of enterprises. The conclusions make up the last section. The article presents which sectors are the most affected, and indicates the most deteriorated indicators dependently on sector. In consequence the authors admit that the sectoral orientation in research on influence of pandemic on small enterprises is the most appropriate.. The authors intentionally focused on small enterprises, as their specific nature indicates ambiguous possibilities of coping with the crisis, which is confirmed by the literature. Our study contributes to the growing amount of literature on the effects of COVID-19 on firms [18][8][16][9]. The research results can be helpful in proper channelling aid to enterprises to recover from crisis. Knowing the weaknesses and the handicaps of particular sectors both the managers/owners and governments may cope better with the restructuring. Seeing the financial security as a significant part of organizational resilience we would like to indicate the sectors and areas in small enterprises finance which are particularly fragile. During the first wave of the pandemic the most of financial support was not diversified and to some extend random. The result of this study can be helpful in building supports plans for particular financial areas in particular sectors in case of future turbulence.

\section{Literature Background}

The unexpected events have influence both on whole economy and on particular entities. The scope the entities can deal with turbulent surrounding is differentiated. Hence, the organizational resilience understood as "the maintenance of positive adjustment under challenging conditions such that the organization emerges from those conditions strengthened and more resourceful" [19] stays the core issue. Primary the term resilience originated from the physical sciences [17] however it was applied in other areas and sectors e.g., ecosystems [20][21] health system [17][22][23] and of course organization, small companies included [24][19][25][26]. Organizational resilience leads to ensure sustainability, even in the face of disaster disruption, and COVID-19 definitely can be considered as an unexpected disaster [27].

In the literature resilience can also be characterized by four interrelated dimensions: technical, organizational, social, and economic [28] where economic is understood "as to the capacity of firms (...) to absorb, contain, or reduce both direct and indirect economic losses resulting from disasters" [28]. What more an organization's financial position and its economic stability are seen as significant 
strengths in terms of resilience [29]. The availability of resources, financial resources included, is an important factor that influences the organizational resilience [17][29]. Financial resources (cash flow and liquidity) and budgetary control and financial reserves were indicated as important factors influencing resilience [30]. Lack of resilience is visible in financial ratios deterioration and leads to financial security problems. According to Pal et. $\mathrm{Al}$ [30] firms with financial constraints, affected by the crises effects report bad financial performance. Additionally, financial resources "can act as a buffer in the face of a crisis" [31], and financial assets can be an important source of organizational resilience [31]. Based on that it can be stated that an organizations' financial standing in a significant factor to its resilience. So, checking the main financial ratios and assessing if the Covid-19 had impact on the financial security in small enterprises, we attempt to contribute to organizational resilience problems.

We focused on small enterprises, because such entities very often rely on the person of the owner, and - as opposed to large companies - they do not have sufficient human capital or financial backup resources. It could seem that this would be the reason why they should be more susceptible to negative effects of crises [32]. A financial crisis affects not only the money supply or investment activity, but it also has its consequences in everyday operations when it is necessary to search for alternative sources of financing, and bank loans are constrained or unavailable [33]. Moreover, their increased dependence on a smaller number of clients, suppliers and markets may lead to increased difficulties in maintaining their business during the crisis [34]. However, the literature provides some arguments which indicate that small enterprises may cope with the crisis effects better than big companies. Due to their flexible structures, SMEs may quickly adapt to innovations, react to demand fluctuations, and faster identify any emerging opportunities [35].

According to Sullivan-Taylor and Branicki [36] small firms can have an advantage in terms of organizational resilience over larger firms, thanks to lower level of bureaucracy, the possibility of rapid decision making and shorter processes. But on the other hand, "small and medium-sized enterprises are more endangered than big enterprises i.e., that their resilience to climatic and other disasters is much smaller due to the fact that they usually are not insured against disasters and that they have limited access to loans, while a majority of them doesn't have business continuity in emergency situations" [37]. Hence, small enterprises should pay more attention to liquidity, cash flows and seasonal fluctuations [37]. During recent months an increase of literature contributes to organizational resilience in context of COVID. The situation of SMEs during Covid in terms of organizational resilience was studied by Klein and Todesco [38], who focused on general weaknesses, strengths, challenges and opportunities for SMEs to face Covid pandemic. Another research focuses on survival strategy under Covid [39]. Zhong [31] in turn studied the organizational resilience in the context of the development of SMEs.

As for ways of financial security evaluation, the literature on the subject provides numerous indicators used in financial analyses of enterprises [15][40][41][42][43]. It also indicates that it is necessary to take into account the non-financial (and in fact off-book) aspects connected with financial security [44][42][45], however, most commonly used measures are financial analysis ratios based on the accrual or cash basis. When assessing the financial security of small enterprises, cash-based ratios may be used to a very limited extent, as such entities as a rule are not obliged to prepare cash flow statements. On the basis of generally accessible statistics in Poland, for the purposes of evaluating the financial security of small enterprises it is thus possible to apply first and foremost accrual-based indicators. Taking into account the financial standing of enterprises, the following areas of creating and providing financial security can be distinguished: sales of products (services), goods and materials, financial liquidity, solvency, profitability, and financial reserves [41]. As the authors intended to examine the immediate effects of the pandemic, i.e., to research the phenomenon while taking a short-term approach, they selected the indicators which are subject to change quickly due to any turbulence in the economy caused by the lockdown. The financial ratios based on the profit and loss account, balance sheet and cash flow statement were many a time applied in the literature not only for the purposes of evaluating the financial standing, but also for anticipating bankruptcy of enterprises [46][47]. Undoubtedly, the key area in the functioning of each enterprise is financial liquidity. In fact, the short-term effects for most SMEs included predominantly liquidity problems and increased financial constraints as a result of disturbances in business activity during lockdowns [13]. The importance of liquidity for financial standing in pandemic times is shown in many studies [6][16][48]. In the case of supply and demand shocks, also sales will be subject to 
decreases. The factors that are relevant from the point of view of evaluating an enterprise's standing also include the volume and growth rate of both revenue and profit. The studies conducted in China after two crises have shown revenues drops among other sharp decreases in many business indicators [49].

\section{Problem Solution}

The most important challenges connected with COVID-19 and SMEs include cashflow deficit, demand reduction and contract breach risk [8], which influence liquidity, sales profitability and the level of both revenues and net profit. Revenues, liquidity and profit margin are commonly used as indicators that are employed to assess financial performance and how firms cope with the recession [50]. Therefore, the following measures and indicators were selected to be applied in the analysis:

- liquidity current ratio - the ratio of current assets of the entity (inventory, short-term receivables, short-term investments and shortterms prepayments) to short-term liabilities (excluding special funds),

- liquidity quick ratio - the ratio of short-term investments and short-term receivables to short-term liabilities (excluding special funds),

- liquidity cash ratio - the ratio of short-term investments and cash to short-term liabilities,

- net profit margin - measured as the ratio of net financial result to revenues (net income/revenue),

- return on sales - the ratio of profit from sales to net revenues from sale of products, goods and materials (gross profit/ sales),

- net revenues from sales of products, goods and materials,

- net financial result.

Under mentioned assumption the authors formulated the following hypothesis: the first wave of the pandemic was reflected in the selected financial security indicators of Polish small enterprises in a diversified manner which depended on the business sector.

The research study applied the desk research method, using the Local Data Bank of the Polish Central Statistical Office (GUS), which was the only possibility to access in short time, the reliable and numerous samples. The financial ratios were obtained for non-financial enterprises employing from 10 to 49 persons, which according to the GUS methodology were considered to be small enterprises. The enterprises to be analysed were categorised into sectors as per PKD (i.e., the official Polish Classification of Business Activity). The sectoral approach was applied both to research on enterprises bankruptcy [47] and to the recent studies on the Covid-19 pandemic effects [18][32][13][8]. To cover all types of small enterprises the study takes into account all the sectors of business activity stipulated by GUS, i.e.: B (mining and extraction), $\mathrm{C}$ (industrial processing), D (production and supply of electric power, gas, steam, hot water and air for air-conditioning systems), E (water supply; waste and waste water management, and land reclamation activities), F (construction industry), G (wholesale and retail trade; motor vehicle repair, including motorcycles), $\mathrm{H}$ (transport and warehousing), I (accommodation and catering services), $\mathrm{J}$ (information and telecommunication), L (real property services), $\mathrm{M}$ (professional, scientific and technical activity), $\mathrm{N}$ (administrative and supporting services), P (education), Q (healthcare and social welfare), $\mathrm{R}$ (activities related to culture, entertainment and recreation), $\mathrm{S}$ (other service activities).

The study focused on a comparative analysis of selected indicators and financial data of small enterprises operating in all the above-mentioned sectors. The period adopted for the comparative analysis was 2016-2020, where the analysed indicators pertained to the first 6 months of each year covered by the study. The comparative analysis results made it possible to evaluate the sensitivity of the individual economy sectors to the effects of the first lockdown caused by Covid-19. We employed p-value to assess the statistical significance of the financial indicators' changes. Next, based on the changes of the basic indicators in the first half of 2020 compared to the four previous years, scores were assigned. Based on the literature review four groups of indicators (liquidity ratios, chosen profitability ratios, revenues and financial result) were assessed for each sector, using a three-grade scale, where -1 means that the values for the 1 st half of 2020 were worse than in the four previous years, 0 means that the given measure was at a similar level, whereas 1 was awarded in the situation when the indicator distinctly improved. The comparative analysis made it possible to specify which business sectors were affected in terms of disturbances in liquidity, profitability, revenues and financial result during the first phase of the pandemic. These findings, in turn, made it possible to identify the sectors and indicators that were the fastest to react 
to the economic lockdown in a short-term perspective.

Further the analysed sectors were divided into four groups based on changes of the selected indicators. The sectors where the mean score fell within the range $\langle 0.5 ; 1\rangle$ were qualified as resistant to the effects of the economic lockdown in the first half of 2020. The sectors with mean scores of $<0 ; 0.5)$ were classified as hardly affected, whereas the ones with the mean scores of $(-0.5 ; 0)$ - as moderately affected by the first lockdown. The enterprises being part of the sectors where the means fell within the range of $<-1 ;-0.5>$ were the ones severely affected by the first phase of the pandemic. Finally, the effects were presented in the matrix showing the most affected sectors and the sectors that did relatively well in the first lockdown. The division in four cluster and the research findings might have both practical and academic implications. Firstly, in the unprecedented lockdown circumstances sectoral approach can lead to more reasonable and purposeful direction of the governmental support and may be helpful for managers and owners in decision making process. Secondly, small companies most of which in Poland are characterized by limited financial information reporting might understand the importance of monitoring financial security. Thirdly, the results emphasize the importance of financial security as a factor of organizational resilience, which basically is seen as an ability of adaptation to complex and changeable surrounding.

According to the literature, financial liquidity may be particularly sensitive to an economic lockdown caused by Covid-19 [13]. Moreover, compared to larger firms, SMEs have less liquidity from external financing or previous years' profits [16]. Table 1 presents the values of the three liquidity ratios over the studied period and their mean values for particular sectors.

Table 1. Liquidity ratios of small enterprises in the selected sectors in the 1st halves of 2016-2020 [\%].

\begin{tabular}{|c|c|c|c|c|c|c|c|c|c|c|c|c|c|c|c|c|c|c|}
\hline & \multicolumn{5}{|c|}{ Cash ratio (CaR) } & \multicolumn{5}{|c|}{ Quick ratio (QR) } & \multicolumn{5}{|c|}{ Current ratio (CR) } & \multicolumn{3}{|c|}{ Mean } \\
\hline Sector & 2016 & 2017 & 2018 & 2019 & 2020 & 2016 & 2017 & 2018 & 2019 & 2020 & 2016 & 2017 & 2018 & 2019 & 2020 & CaR & QR & $\mathbf{C R}$ \\
\hline B & 68 & 46 & 63 & 49 & 48 & 148 & 132 & 136 & 124 & 124 & 176 & 156 & 159 & 142 & 142 & 56 & 135 & 158 \\
\hline C & 38 & 35 & 33 & 35 & 54 & 121 & 112 & 110 & 108 & 133 & 174 & 161 & 159 & 157 & 190 & 35 & 112 & 163 \\
\hline D & 33 & 64 & 56 & 64 & 67 & 90 & 110 & 109 & 128 & 120 & 104 & 121 & 123 & 148 & 143 & 54 & 109 & 124 \\
\hline $\mathbf{E}$ & 80 & 84 & 71 & 67 & 79 & 181 & 187 & 159 & 145 & 159 & 205 & 210 & 180 & 166 & 181 & 75 & 168 & 190 \\
\hline $\mathbf{F}$ & 43 & 43 & 46 & 48 & 51 & 114 & 118 & 121 & 127 & 118 & 169 & 179 & 187 & 197 & 183 & 45 & 120 & 183 \\
\hline $\mathbf{G}$ & 28 & 25 & 25 & 25 & 38 & 100 & 96 & 94 & 97 & 110 & 161 & 155 & 152 & 157 & 175 & 26 & 97 & 156 \\
\hline $\mathbf{H}$ & 40 & 55 & 69 & 35 & 46 & 163 & 125 & 182 & 153 & 154 & 174 & 131 & 195 & 165 & 166 & 50 & 156 & 166 \\
\hline I & 60 & 53 & 49 & 63 & 62 & 103 & 94 & 92 & 105 & 111 & 119 & 109 & 107 & 122 & 131 & 56 & 98 & 114 \\
\hline $\mathbf{J}$ & 48 & 59 & 63 & 69 & 84 & 141 & 158 & 149 & 156 & 177 & 165 & 195 & 183 & 184 & 209 & 60 & 151 & 182 \\
\hline $\mathbf{L}$ & 117 & 122 & 122 & 121 & 126 & 155 & 162 & 161 & 154 & 158 & 197 & 201 & 207 & 195 & 213 & 120 & 158 & 200 \\
\hline $\mathbf{M}$ & 50 & 106 & 56 & 54 & 63 & 108 & 202 & 99 & 104 & 130 & 122 & 224 & 110 & 118 & 150 & 67 & 128 & 143 \\
\hline $\mathbf{N}$ & 32 & 41 & 33 & 40 & 63 & 85 & 120 & 82 & 97 & 132 & 99 & 136 & 100 & 111 & 148 & 37 & 96 & 111 \\
\hline $\mathbf{P}$ & 75 & 94 & 112 & 572 & 99 & 135 & 149 & 176 & 872 & 143 & 148 & 166 & 197 & 889 & 154 & 213 & 333 & 350 \\
\hline $\mathbf{Q}$ & 83 & 91 & 84 & 100 & 120 & 173 & 177 & 174 & 195 & 206 & 185 & 188 & 183 & 206 & 217 & 90 & 180 & 191 \\
\hline $\mathbf{R}$ & 35 & 47 & 53 & 23 & 34 & 81 & 95 & 114 & 51 & 64 & 94 & 112 & 133 & 59 & 77 & 39 & 85 & 100 \\
\hline $\mathbf{S}$ & 38 & 37 & 43 & 41 & 50 & 107 & 121 & 107 & 182 & 128 & 133 & 148 & 138 & 201 & 155 & 40 & 129 & 155 \\
\hline
\end{tabular}

Source: own study based on statistical data obtained from www.stat.gov.pl

The literature indicates some limitations regarding the normative values of the liquidity ratios. Hence, the liquidity is highly diversified across sectors, moreover each enterprise has its own specifics in terms of shaping its current assets and liabilities [52][53]. In this research study we did not compare the values of liquidity ratios among different sectors, but the changes in the values of liquidity ratios in the same sector over time, so the differentiation did not influence the findings.
According to the Polish literature on the subject [51], assessment of cash ratios should be based on comparison over time, as there are no specified standard values for them. In order to assess the cash ratio value in the 1 st half of 2020 , it was compared to the mean value observed in the years 2016-2019. The lower values of the indicator (i.e., showing deterioration of the cash ratio) have been marked grey. The results have demonstrated that five sectors showed a decrease in the cash ratio in the first half 
of 2020 compared to the previous years However the values of cash ratio indicate rather overliquidity in all studied periods, hence the deterioration did not caused payment problems. The ratio shows that small enterprises in Poland kept the cash cushion.

In relation to the quick ratio and current ratio values, the Polish literature provides standard values, i.e., the quick ratio value should be around 1 (100\%), or even it is claimed that only when the ratio is above 1 $(100 \%)$ it is possible for an enterprise to meet its current liabilities on a current basis [51]. The current ratio, in turn, pursuant to the standards should be around $1.2-2.0$ or $1.5-2.0$ (i.e., $120-200 \%$ or 150-200\%) [51]. When the ratios exceed the standard levels, it means overliquidity, whereas their values below the standard levels indicate that the enterprise may have problems with meeting its liabilities in due time. When assessing the values of the quick ratio and current ratio, first their 2020 values were compared to their means for the years 2016-2019. Next, the ratios were compared against the optimal ones. The ratios which fell below the mean or the standard have been marked grey.

Regarding the quick ratio, Table 1 shows that in the case of seven sectors the value of the indicator in 2020 was lower than the mean from the previous years. But generally, it can be stated that similarly to previous periods the liquidity in all sectors was on the safe level. The differences were slight. It should also be noted that apart from sector $\mathrm{R}$ (activities related to culture, entertainment and recreation), all the other sectors demonstrated the ratio values at a satisfactory level, i.e., above $100 \%$. Therefore, one may tempted to conclude that the quick ratio values do not indicate a deterioration of the solvency standing of small enterprises in the studied period. Analogous conclusions may be drawn from the analysis of the current ratio values. Apart from sector $\mathrm{R}$, its values for all the other sectors fall within the ranges stipulated in the literature. What is more, most sectors met the higher standard, i.e., 150-200\%. Thus, impacts of the 1st phase of the pandemic are not reflected in the current ratio values. Based on the ratio values shown in Table 1, it is possible to conclude that in the 1st half of 2020 the financial security of enterprises in terms of liquidity should be deemed positive. Although the impact of different crises on the liquidity is emphasized in many studies and as a financial buffer contributes to organizational resilience, in the first months of the pandemic the problem was not reflected in the indicators.

Table 2. Sales profitability ratios of small enterprises in the selected sectors in the 1st halves of 2016-2020.

\begin{tabular}{|c|c|c|c|c|c|c|c|c|c|c|c|c|}
\multicolumn{1}{c|}{} & \multicolumn{3}{|c|}{ Net Profit Margin (NPM) } & \multicolumn{4}{c|}{ Return on Sales (ROS) } & \multicolumn{2}{c|}{ Mean } \\
\hline Sector & $\mathbf{2 0 1 6}$ & $\mathbf{2 0 1 7}$ & $\mathbf{2 0 1 8}$ & $\mathbf{2 0 1 9}$ & $\mathbf{2 0 2 0}$ & $\mathbf{2 0 1 6}$ & $\mathbf{2 0 1 7}$ & $\mathbf{2 0 1 8}$ & $\mathbf{2 0 1 9}$ & $\mathbf{2 0 2 0}$ & NPM & ROS \\
\hline B & -23.5 & 4.2 & 4 & 7.1 & 11.2 & -1.3 & 4 & 3.5 & 4.8 & 11.1 & -1.64 & 2.75 \\
\hline C & 6.1 & 5.9 & 6 & 5.9 & 7.2 & 6.7 & 5.4 & 6.4 & 6.3 & 7 & 4.78 & 6.20 \\
\hline D & -0.9 & -0.1 & 2.8 & 2.8 & 2.5 & 3.9 & 6.4 & 3.4 & 3 & 5.1 & 0.92 & 4.18 \\
\hline E & 5.7 & 4.1 & 4.1 & 5.3 & 7.6 & 4.8 & 3.9 & 4.1 & 5.6 & 7.3 & 3.84 & 4.60 \\
\hline F & 4.2 & 4.5 & 7.8 & 8.8 & 7 & 3.8 & 3.9 & 7.5 & 6.9 & 7 & 5.06 & 5.53 \\
\hline G & 3.3 & 3.4 & 3.6 & 3.6 & 4.7 & 3.7 & 3.6 & 4.1 & 3.9 & 4.9 & 2.78 & 3.83 \\
\hline H & 7.7 & 5.6 & 3.6 & 6.5 & 4.3 & 7.3 & 7.2 & 7.9 & 6.5 & 8.1 & 4.68 & 7.23 \\
\hline I & 4.1 & 5 & 5.7 & 3.9 & -6.4 & 6.9 & 5.8 & 7.7 & 4.8 & -13 & 3.74 & 6.30 \\
\hline J & 3.6 & 3.9 & 3.1 & 5.1 & 6.1 & 5 & 5.4 & 4.4 & 5.5 & 6 & 3.14 & 5.08 \\
\hline L & 12.4 & 7.4 & 6.3 & 6.9 & 5.6 & 7.6 & 7.1 & 7.4 & 6.6 & 4.9 & 6.6 & 7.18 \\
\hline M & 4.3 & 14.6 & 14.1 & 11.3 & 11.2 & 3.3 & 5.1 & 3.9 & 7 & 9.7 & 8.86 & 4.83 \\
\hline N & 4.8 & 3.6 & 4.6 & 6 & 6 & 6 & 5.1 & 6.4 & 6.3 & 5 & 3.8 & 5.95 \\
\hline P & 0.9 & 7.4 & 5.4 & 3.8 & 4.8 & -14.7 & -23.4 & -31.6 & -40.6 & -34 & 3.5 & 27.58 \\
\hline Q & 5.7 & 5.1 & 5.8 & 6.8 & 7.6 & 6.6 & 5.7 & 6 & 6.9 & 7.2 & 4.68 & 6.30 \\
\hline R & -5.5 & -8.3 & -0.8 & -5.5 & -22.5 & -12.9 & -16.6 & -5.7 & -10.3 & -27.1 & -4.02 & 11.38 \\
\hline S & 5.9 & 4.4 & 3.1 & -1.8 & 1.3 & 7.4 & 5.1 & 2.6 & 3.1 & -1.4 & 2.32 & 4.55 \\
\hline
\end{tabular}

Source: own study based on statistical data obtained from www.stat.gov.pl

The lockdown entailed not only constraints in people's mobility, but first and foremost suspension of many enterprises' business activity. A pandemic may certainly be classified as one of unanticipated events that, according to research studies results, lead to a systematic decrease in sales profitability 
ratios [54]. Thus, sales profitability may seem to be the area where any changes in the business environment are reflected almost instantly (Table 2). As for the net profit margin (NPM) indicator, negative values were identified in two sectors: I (accommodation and catering services) and $\mathrm{R}$ (activities related to culture, entertainment and recreation), whereas in three sectors the ratio values were lower than the mean for the previous years. In table 2 is to see that a similar situation was in the case of the ROS ratio, as negative values were found not only in sector I (accommodation and catering services) and $\mathrm{R}$ (activities related to culture, entertainment and recreation), but also in sector $\mathrm{P}$ (education). However, it should be noted that sector $\mathrm{R}$ showed negative values of the sales profitability ratios also in the previous years. Still, as in 2020 their levels were definitely lower, it may be concluded that the effects of the lockdown are perceivable for this sector. Nevertheless, a different approach should be taken when assessing the ROS value for sector $\mathrm{P}$ (education). Its level was negative also in the years 2016-2019, while in 2019 it was even lower than in 2020, which suggests that the low level of this indicator may not be connected only with the pandemic. The turnover decreased considerably also in sector I (accommodation and catering services), as in the years preceding 2020 the sales profitability ratios were positive for this sector. It seems that the sector I was the most severely affected by the lockdown. Sales ratios indicate the demand changes and together with the revenues can be seen as most sensitive indicators.

Table 3. Revenues growth index of small enterprises in the selected sectors in the 1st halves of 2016-2020

\begin{tabular}{|c|r|r|r|r|r|r|r|r|r|}
\cline { 8 - 11 } \multicolumn{1}{c|}{} & \multicolumn{4}{|c|}{ Revenues growth index } & \multicolumn{4}{|c|}{ Revenues growth index } \\
\hline Sector & $\mathbf{2 0 2 0 / 2 0 1 6}$ & $\mathbf{2 0 2 0 / 2 0 1 7}$ & $\mathbf{2 0 2 0 / 2 0 1 8}$ & $\mathbf{2 0 2 0 / 2 0 1 9}$ & Sector & $\mathbf{2 0 2 0 / 2 0 1 6}$ & $\mathbf{2 0 2 0 / 2 0 1 7}$ & $\mathbf{2 0 2 0 / 2 0 1 8}$ & $\mathbf{2 0 2 0 / 2 0 1 9}$ \\
\hline B & $123 \%$ & $111 \%$ & $112 \%$ & $129 \%$ & $\mathbf{J}$ & $126 \%$ & $123 \%$ & $119 \%$ & $102 \%$ \\
\hline $\mathbf{C}$ & $92 \%$ & $93 \%$ & $102 \%$ & $92 \%$ & $\mathbf{L}$ & $105 \%$ & $102 \%$ & $102 \%$ & $99 \%$ \\
\hline $\mathbf{D}$ & $129 \%$ & $140 \%$ & $159 \%$ & $81 \%$ & $\mathbf{M}$ & $123 \%$ & $114 \%$ & $109 \%$ & $99 \%$ \\
\hline $\mathbf{E}$ & $128 \%$ & $116 \%$ & $104 \%$ & $103 \%$ & $\mathbf{N}$ & $103 \%$ & $88 \%$ & $111 \%$ & $81 \%$ \\
\hline $\mathbf{F}$ & $123 \%$ & $129 \%$ & $100 \%$ & $112 \%$ & $\mathbf{P}$ & $72 \%$ & $86 \%$ & $115 \%$ & $72 \%$ \\
\hline $\mathbf{G}$ & $96 \%$ & $93 \%$ & $102 \%$ & $92 \%$ & $\mathbf{Q}$ & $102 \%$ & $105 \%$ & $106 \%$ & $95 \%$ \\
\hline $\mathbf{H}$ & $103 \%$ & $99 \%$ & $102 \%$ & $101 \%$ & $\mathbf{R}$ & $234 \%$ & $246 \%$ & $142 \%$ & $144 \%$ \\
\hline $\mathbf{I}$ & $106 \%$ & $97 \%$ & $113 \%$ & $82 \%$ & $\mathbf{S}$ & $66 \%$ & $82 \%$ & $92 \%$ & $84 \%$ \\
\hline
\end{tabular}

Source: own study based on statistical data obtained from www.stat.gov.pl

The next measures covered by the analysis were revenue volumes and financial result (Table 3 and Table 4). The level of revenues, and especially revenue growth rate, are very important in terms of assessing the financial standing of small enterprises as a result of the lockdown. The level of revenue and its growth rate may be warning signals of a deteriorating economic situation of an enterprise. Moreover, a decrease in revenues was one of the conditions for obtaining support from the Polish government under the so called Anti-Crisis Shield programme [55], which confirms its relevance in evaluating sensitivity to the pandemic effects. The revenue growth index analysis was made by comparing the 2020 revenue to the revenues of the preceding years. The results (in table 3 ) have shown that only in the case of sector $\mathrm{S}$ (other service activities) the revenue was lower compared to all of the four previous periods. Whereas in three sectors: $\mathrm{C}$ (industrial processing), $\mathrm{G}$ (wholesale and retail trade; motor vehicle repair, including motorcycles), and $\mathrm{P}$ (education) the 2020 revenues were lower than in the three preceding years. Sector $\mathrm{R}$ (activities related to culture, entertainment and recreation), which in terms of liquidity and profitability was at the end of the ranking, in 2020 showed revenues exceeding those of the previous years - despite the lockdown. At the same time it is the sector which in all the analysed years showed a negative financial result (table 4), which may result from a high level of costs. Even though over all the studied years the financial result of sector $\mathrm{R}$ was negative, in the first half of 2020 its level was as much as six times lower compared to the 1st half of 2019. A negative financial result for the first half of 2020 was also shown by sector I (accommodation and catering services). Lower financial results were also seen in sector L (real property services), $\mathrm{P}$ (education), $\mathrm{S}$ (other service activities), which is clear to observe in table 4. Quite stable level or even growth is visible in sector $(\mathrm{C}$ industrial processing), E (water supply; waste and waste water 
management, and land reclamation activities), $\mathrm{G}$ (wholesale and retail trade; motor vehicle repair, including motorcycles), $\mathbf{J}$ (information and telecommunication), Q (healthcare and social welfare).

Table 4. Net financial results of small enterprises in the selected sectors in the 1st halves of 2016-2020.

\begin{tabular}{|c|c|c|c|c|c|c|}
\hline & \multicolumn{5}{|c|}{ Financial result (k PLN) } & \multirow[b]{2}{*}{$\begin{array}{c}\text { mean } \\
2016- \\
2020 \\
\end{array}$} \\
\hline Sector & 2016 & 2017 & 2018 & 2019 & 2020 & \\
\hline B & $-129,364$ & 26,081 & 25,171 & 37,994 & 75,777 & $-10,030$ \\
\hline C & $2,167,539$ & $2,101,853$ & $2,083,591$ & $2,098,111$ & $2,349,758$ & $2,112,774$ \\
\hline D & $-47,823$ & $-7,131$ & 150,658 & 243,125 & 173,840 & 84,707 \\
\hline $\mathbf{E}$ & 136,747 & 105,863 & 115,657 & 156,898 & 230,627 & 128,791 \\
\hline $\mathbf{F}$ & 651,336 & 655,196 & $1,314,770$ & $1,499,959$ & $1,304,468$ & $1,030,315$ \\
\hline $\mathbf{G}$ & $4,028,799$ & $4,359,965$ & $4,622,174$ & $4,590,117$ & $5,520,188$ & $4,400,264$ \\
\hline $\mathbf{H}$ & 888,288 & 681,103 & 412,392 & 753,797 & 513,457 & 683,895 \\
\hline I & 65,898 & 88,545 & 102,533 & 79,337 & $-116,795$ & 84,078 \\
\hline $\mathbf{J}$ & 203,931 & 228,081 & 180,699 & 359,482 & 436,701 & 243,048 \\
\hline $\mathbf{L}$ & 855,044 & 494,983 & 419,628 & 469,539 & 382,993 & 559,799 \\
\hline $\mathbf{M}$ & 274,308 & $1,170,067$ & $1,174,926$ & 952,758 & 938,694 & 893,015 \\
\hline $\mathbf{N}$ & 152,293 & 134,244 & 168,616 & 241,813 & 204,066 & 174,242 \\
\hline $\mathbf{P}$ & 4,303 & 35,667 & 27,939 & 23,451 & 21,655 & 22,840 \\
\hline $\mathbf{Q}$ & 138,388 & 121,220 & 141,410 & 177,159 & 191,917 & 144,544 \\
\hline $\mathbf{R}$ & $-33,182$ & $-48,326$ & $-5,677$ & $-53,414$ & $-303,764$ & $-35,150$ \\
\hline $\mathbf{S}$ & 25,859 & 15,676 & 12,007 & $-6,186$ & 3,757 & 11,839 \\
\hline
\end{tabular}

Source: own study based on statistical data obtained from www.stat.gov.pl

The Student's t-test was also employed to verify statistically significance of changes in the values of financial ratios. For the null hypothesis, which proposes that there were no statistically significant changes in the values of the above indicators in 2020, the alternative hypothesis was contrasted. The alternative hypothesis indicated that the level of a given indicator changed significantly compared to its average level in the previous four years. The assumption of statistical significance is at a level of $p$-value $\leq 0,05$ (rejection of the null hypothesis in favor of the alternative hypothesis).

Table 5. P-value for particular financial ratios

\begin{tabular}{|l|l|l|l|l|l|l|l|}
\cline { 2 - 8 } Sector & \multicolumn{7}{|c|}{ p-value } \\
\hline & CaR & QR & CR & NPM & ROS & Revenues & $\begin{array}{l}\text { Net } \\
\text { financial } \\
\text { result }\end{array}$ \\
\hline B & 0,209 & 0,115 & 0,102 & 0,162 & 0,009 & 0,0153 & 0,121 \\
\hline $\mathbf{C}$ & 0,000 & 0,006 & 0,006 & 0,000 & 0,065 & 0,0007 & 0,001 \\
\hline $\mathbf{D}$ & 0,180 & 0,260 & 0,127 & 0,257 & 0,313 & 0,3913 & 0,281 \\
\hline $\mathbf{E}$ & 0,438 & 0,424 & 0,440 & 0,007 & 0,006 & 0,0833 & 0,003 \\
\hline $\mathbf{F}$ & 0,016 & 0,518 & 1,000 & 0,601 & 0,228 & 0,0128 & 0,303 \\
\hline $\mathbf{G}$ & 0,000 & 0,002 & 0,002 & 0,000 & 0,002 & 0,0075 & 0,004 \\
\hline $\mathbf{H}$ & 0,659 & 0,892 & 0,986 & 0,171 & 0,055 & 0,2497 & 0,187 \\
\hline $\mathbf{I}$ & 0,170 & 0,030 & 0,020 & 0,000 & 0,000 & 0,3245 & 0,000 \\
\hline $\mathbf{J}$ & 0,012 & 0,007 & 0,022 & 0,014 & 0,034 & 0,0391 & 0,017 \\
\hline $\mathbf{L}$ & 0,019 & 1,000 & 0,016 & 0,155 & 0,002 & 0,2381 & 0,174 \\
\hline $\mathbf{M}$ & 0,808 & 0,948 & 0,825 & 0,961 & 0,009 & 0,1057 & 0,844 \\
\hline
\end{tabular}




\begin{tabular}{|l|l|l|l|l|l|l|l|}
$\mathbf{N}$ & 0,001 & 0,025 & 0,024 & 0,085 & 0,049 & 0,1269 & 0,295 \\
\hline $\mathbf{P}$ & 0,411 & 0,368 & 0,356 & 0,777 & 0,330 & 0,0172 & 0,870 \\
\hline $\mathbf{Q}$ & 0,004 & 0,015 & 0,015 & 0,016 & 0,046 & 0,7308 & 0,027 \\
\hline $\mathbf{R}$ & 0,469 & 0,208 & 0,247 & 0,002 & 0,006 & 0,0048 & 0,000 \\
\hline $\mathbf{S}$ & 0,005 & 0,949 & 1,000 & 0,408 & 0,012 & 0,0245 & 0,313 \\
\hline
\end{tabular}

\section{Source: own study}

P-value calculated for all liquidity ratios for sectors C, G, J, N, Q meets an acceptable level of statistical significance $(p \leq 0,5)$. In the case of sales profitability indicators, it can be stated that there was a statistically significant change in the first half of 2020 compared to the average value in the previous periods in sector $\mathrm{E}, \mathrm{G}, \mathrm{I}, \mathrm{J}, \mathrm{Q}, \mathrm{R}$. The revenue analysis shows a statistically significant change in eight sectors (B, C, F, G, J, P, R, S), while the value of net profit changed statistically significantly in seven sectors (C, E, G, I, J, Q, R).

Based on values of chosen financial indicators (tables: 1,2,3, and 4) authors conducted the evaluation of the individual financial areas in the context of immediate effects of the Covid-19 pandemic. The evaluation of the individual sectors takes into account the p-value and was based on how the indicators for the 1st half of 2020 changed in comparison to the previous years, the results are in table 6.

Table 6. Evaluation of the individual areas of financial security of small enterprises in the 1st half of 2020 (by sectors).

\begin{tabular}{|c|c|c|c|c|c|c|c|c|c|c|c|c|c|c|c|c|}
\hline & B & C & D & $\mathbf{E}$ & $\mathbf{F}$ & G & $\mathbf{H}$ & I & $\mathbf{J}$ & L & M & $\mathbf{N}$ & $\mathbf{P}$ & $\mathbf{Q}$ & $\mathbf{R}$ & $\mathbf{S}$ \\
\hline liquidity & 0 & 0 & 0 & 0 & 0 & 1 & 0 & 1 & 0 & 0 & 0 & 1 & 1 & 0 & -1 & 0 \\
\hline profitability & 1 & 1 & 1 & 1 & 0 & 1 & 0 & -1 & 1 & -1 & 1 & 0 & 0 & 1 & -1 & -1 \\
\hline revenues & 0 & -1 & 0 & 1 & 1 & -1 & 0 & -1 & 1 & 0 & 0 & -1 & -1 & 0 & 1 & -1 \\
\hline $\begin{array}{l}\text { financial } \\
\text { result }\end{array}$ & 1 & 1 & 0 & 1 & -1 & 1 & -1 & -1 & 1 & -1 & -1 & 0 & -1 & 1 & -1 & -1 \\
\hline Mean & 0.5 & 0.25 & 0.25 & 0.75 & 0 & 0.5 & -0.25 & -0.5 & 0.75 & -0.5 & 0 & 0 & -0.25 & 0.5 & -0.5 & -0.75 \\
\hline
\end{tabular}

Source: own work

The value of -1 means that the indicator level deteriorated in the 1 st half of 2020 , the value of 0 is assigned in the situation when the indicator value was at a similar level as in the preceding periods, whereas the value of 1 was granted when the indicator level was better than in the previous years. The value of 1 for liquidity was assigned to the sector where the liquidity ratios improved, and in the first half of 2020 were consistent with the optimum values. In the area of sales profitability, revenues and financial result, 1 was assigned to the sectors where the values in the 1 st half of 2020 were higher than in the previous periods or higher than the mean for the previous periods. In the area of liquidity, -1 was assigned to the sectors where the liquidity ratios were below the accepted standards, whereas in the area of sales profitability, revenues and financial result - when the values for the 1st half of 2020 were lower than the ones for at least two preceding periods and/or lower than the mean for the previous periods.

The presented data have shown deteriorated indicators in as many as three areas of financial security evaluation: sector I (accommodation and catering services), $\mathrm{R}$ (activities related to culture, entertainment and recreation), and $\mathrm{S}$ (other service activities), which in principle is coherent with the general media coverage. What is more, in all the three sectors the deterioration was observed in the area of sales profitability and financial result level, whereas only one sector - namely $\mathrm{R}$ - experienced problems with financial liquidity. However, it should be stressed that problems with liquidity in this sector occurred also in the preceding years, so it is possible that they should not be associated directly with the pandemic.

In general, it should be noted that in the first phase of the pandemic it was the liquidity ratios that were very stable, as compared to their levels of 20162019. In the vast majority of the sectors, enterprises maintained the liquidity ratios in accordance with the adopted standards, and even on a higher level, which may be interpreted as overliquidity. This could lead to a conclusion that the lockdown in the initial phase of the pandemic did not have a negative impact on the liquidity of small enterprises in 
Poland. However, it is still unknown - there are not yet any studies result in this regard - how effective the support tools prepared and implemented by the Polish government turned out to be. Maybe it was the support provided to the enterprises that made it possible for them to maintain the financial liquidity. The financial result decreased in eight out of the sixteen sectors, whereas revenues dropped in six of them. It is in these two areas that the deterioration of the financial standing is the most noticeable. Profitability is an area that significantly differentiates the individual sectors. In eight of them, the situation improved, namely in: B (mining and extraction), $\mathrm{C}$ (industrial processing), $\mathrm{D}$ (production and supply of electric power, gas, steam, hot water and air for air-conditioning systems), E (water supply; waste and waste water management, and land reclamation activities), G (wholesale and retail trade; motor vehicle repair, including motorcycles), $\mathrm{J}$ (information and telecommunication), $\mathrm{M}$ (professional, scientific and technical activity), Q (healthcare and social welfare). In four other sectors the profitability remained at a similar level as in the previous periods, namely in: $\mathrm{F}$ (construction industry), $\mathrm{H}$ (transport and warehousing), $\mathrm{N}$ (administrative and supporting services), P (education). Based on the scores assigned to the analysed areas of financial security $(1,0$, or -1$)$, at the next stage of the study a mean value for each sector was computed, which made it possible to draw up a matrix of sectors (Figure 1).

The segmentation of sectors based on changes in financial indicators was inspired by the work of Gourinchas [32], where quite similar sectors segmentation is employed. However, those studies regarded bankruptcy rate in the context of COVID19. Based on chosen indicators values, the sectors were divided into three groups: mildly affected, moderately affected, highly affected [32].

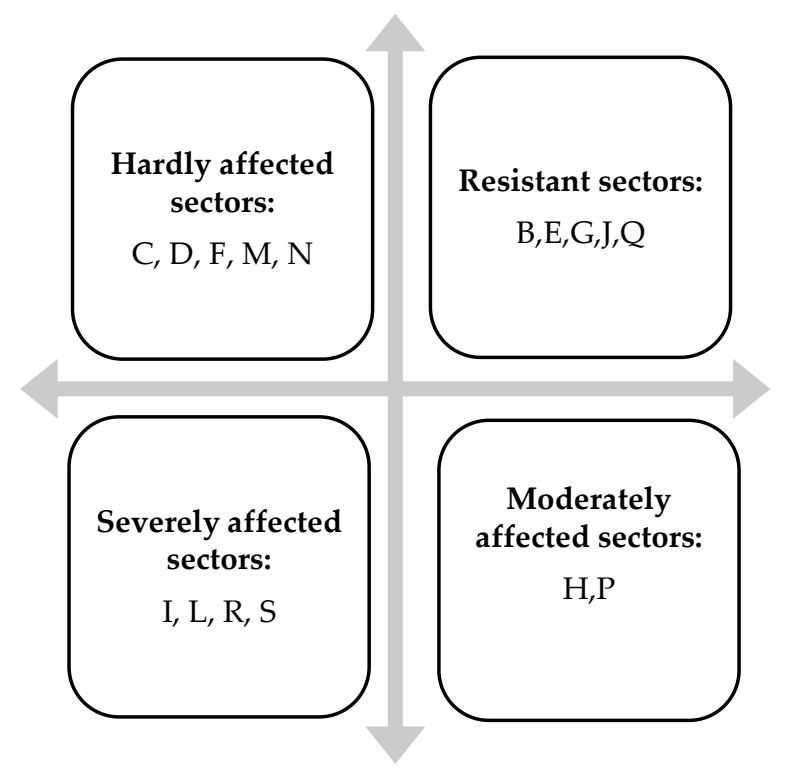

Fig.1: Matrix of responses of particular sectors of small enterprises to immediate effects of the Covid-19 pandemic.

Source: own work.

In our studies to be qualified as a resistant sector, it was necessary to obtain a mean score from 0.5 to 1 in the four analysed areas of financial security. Resistant sectors were: B (mining and extraction), E (water supply; waste and waste water management, and land reclamation activities), $\mathrm{G}$ (wholesale and retail trade; motor vehicle repair, including motorcycles), J (information and telecommunication), Q (healthcare and social welfare). The hardly affected sectors were the ones where the mean fell within the range of $<0 ; 0,5)$ and they included: $\mathrm{C}$ (industrial processing), D (production and supply of electric power, gas, steam, hot water and air for air-conditioning systems), F (construction industry), M (professional, scientific and technical activity), N (administrative and supporting services). The moderately affected sectors were the ones where the mean fell within the range of $(-0,5 ; 0)$, i.e.: $\mathrm{H}$ (transport and warehousing) and $\mathrm{P}$ (education). The sectors that were the most severely affected during the first phase of the pandemic were: sector I (accommodation and catering services), L (real property services), $\mathrm{R}$ (activities related to culture, 
entertainment and recreation), $\mathrm{S}$ (other service activities).

\section{Discussion}

The evolution of the pandemic has been the object of many research [56][57][58]. The number of publications regarding the impact of the Covid-19 pandemic on various aspects of enterprises functioning has been on the rise. Due to the short time since the beginning of the pandemic, most of the studies were based on fragmentary data with a quite limited scope. So far it was possible to look at the pandemic from a perspective of several months. Also, in this article the authors concentrated on a short term and decided to diagnose changes in the basic indicators of financial security of small enterprises, applying a sectoral approach. The influence of crisis on SMEs financial performance from the point of view of organizational resilience was studied by Pal et al [30]. Although in that paper one sector was taken into consideration, the importance of major conclusion that companies can "develop their resilience potential by tuning their strategic assets and capabilities" [30] can be adopted on all sectors. Crises can be seen as well as a chance, which is proved in educational sector [59]. Research showed that the educational sector can quite easily adopted to online reality [59], hence it is more that probable that also in other sectors the lockdown forced a shift towards inclusion of innovation.

In times of a crisis such as the Covid-19 epidemic, dependence of the whole SME sector on bank financing and inability to use in short-run other sources of finance may transform the temporary liquidity shortage into an insolvency problem [32]. Moreover, as other studies indicate, in comparison to larger firms' small enterprises are more likely to report liquidity or cash flow problems due to COVID-19 consequently the longer the crisis persists, the more likely it is that decreased liquidity will lead to insolvency and firm exit [16]. Therefore, the issue of financial liquidity of enterprises appears to be of key importance. The results of the studies described in this article have shown that in the first phase of the pandemic the Polish small enterprises maintained secure levels of financial liquidity. The reason for the good level of liquidity may be the result of the governmental support. In Poland, similarly as in other countries, enterprises had the opportunity to use the support extended by the government [55][60][61], which certainly could be reflected in the results. The results of the surveys held among Japanese entrepreneurs [14] - who were also seriously affected by immediate effects of the pandemic - have shown the need for the government support measures to keep balance between the epidemiological and economic goals (particularly in terms of long-term economic goals). Męcina [60] also underlines the need for long-term thinking in the context of the support measures taken by the government, indicating that they should take an at least 2-year perspective.

This research study pertains to the first period of the pandemic, but it is the first months that are of key importance for survival, which was confirmed by the studies completed by McKinsey Company [62] in August 2020, involving 2200 enterprises based in Germany, France, Great Britain, Italy and Spain. More than a half of the surveyed respondents already in the first phase of the pandemic thought that their enterprises might not survive more than 12 months, despite the fact that $20 \%$ of them had received subsidies from the government (and further $30 \%$ of them declared they were seeking such assistance). Individual governments have been providing various forms of support for SMEs, which to a large extent depends on the local market conditions. $70 \%$ of the surveyed companies declared that their revenues had dropped as a result of the pandemic. Among the industrial sectors, by far the most bankruptcies were anticipated by the logistics sector (22\%), followed by agriculture, hotel and catering enterprises, retail and wholesale, though to a much smaller extent (13-15\%) [62]. Another study indicated that most SMEs faced by an external shock were more willing to limit any negative cash flows or declare bankruptcy rather than to increase its debt-to-equity ratio [63], especially as the cost of credit and loans contracted during the crisis was much higher [64]. On the other hand, small companies may succeed in response to the COVID19 pandemic since this group of entities have already showed great resilience [11]. Basically, it is quite sure that small companies cannot rely only on themselves, but they are dependent on governmental support, creditors policy and general macroeconomic environment.

The short-term approach, though biased in view of limited access to data, in the case of this pandemic seems to be rational. The Covid-19 crisis is more severe than any other crisis in history and its negative effects for the economy occurred immediately. 5 weeks after the onset of the crisis in the USA, the weekly number of lost jobs was higher than after several quarters in the case of other crises [65]. The study conducted in the USA in March 2020 and involving 5,800 small enterprises has shown that they extensively suffered immediate 
effects of the pandemic. $43 \%$ of the surveyed companies had to be temporarily closed due to the Covid-19 pandemic. According to the respondents, the reason for the closing was a decreased demand and health problems of their employees [18]. What is more, negative moods among entrepreneurs in the USA did not improve despite the fact the governmental support was provided (CARES Act) [12]. The companies reported that they had reduced employment on average by $40 \%$. The results of the research study completed in this paper seem to be consistent with the studies based on a sectoral approach, conducted in the USA. According to the results of the American studies, the most severely affected sectors were retail trade, arts and culture, personal services, catering and hotel services, where the reduction in employment exceeded $50 \%$. Smaller disturbances were found in the financial sector, professional services and real estate agencies [18]. Hence, our finding consistent with the results of American economy can be useful in building sectoral approach in organizational resilience. The volatility, uncertainty, complexity and ambiguity of economic surrounding is paradoxical one certain thing [31] and as such build the challenges for firms. The studies carried out by the International Monetary Fund (IMF) in several countries and published in August 2020 focused on SMEs bankruptcies caused by the Covid-19 pandemic. The number of business failures across all countries was estimated to have doubled (an increase from $9.4 \%$ to 18.2\%) [32]. That study also applied the sectoral approach. The research results have shown that the bankruptcy indicators vary significantly, depending on the sector, and the most severely affected sectors were the customer-oriented ones (accommodation, catering, arts, entertainment, recreation, education). This is consistent with the research results presented in this paper as well as in the studies completed by OECD [66]. In the study covering the G7 economies it was shown that in the case of the service-related sectors the mobility constraints and social distancing had a clearly negative impact on any activities involving travel, including tourism and direct contacts between customers and service providers, i.a. hair styling salons. Also, the study described in this article has qualified the "other service activities" sector as one of the severely affected sectors, i.e., one where the financial security level deteriorated due to the pandemic. Hence, it is not surprising that the lockdown hit the most all kind services that could not be transferred to digital world. Base on that the digital transformation although creates opportunities [38], cannot be taken for granted as an organizational resilience tool, since it lacks the universal character. In case of sectors where personal contact is requisite the proper financial buffer seems to gain on importance as a factor of organizational resilience. Which is even more important in case of small companies suffering often financial constraints.

Summing up, the presented research results are coherent with the results of the hitherto published studies on the impacts of the Covid-19 pandemic on the financial standing of enterprise. Nevertheless, it seems that the levels of liquidity ratios reported by the assessed enterprises were better than expected based on the literature [6][16][48]. However, there are no studies that would make it possible to find out unequivocally whether the high liquidity level was due to subsidies provided by the government to the enterprises during the lockdown or whether that was the effect of cash resources accumulated in the previous periods. Anyway, the tools and measure to the liquidity improvement are not very sophisticated and basically demands the cash. Much more difficult is sales and financial results improvement. The drop in revenues and profitability ratios was not severe in most sectors, although according to the research studies results, the pandemic led to a systematic decrease in sales profitability ratios [54]. Nevertheless, deterioration of the financial standing was manifested by the drop in financial results, which was reported in eight sectors.

\section{Conclusion}

The considerations and research results presented herein make it possible to evaluate how the immediate effects of the Covid-19 pandemic were reflected in the financial security indicators of small enterprises in Poland in the first half of 2020. The study is actual, based on the newly published data, and focus not on whole group of small enterprises but the sectoral approach was employed. The study included only selected measures that made it possible to assess the response of enterprises to the first phase of the pandemic, which was the conscious assumption. The research results enable a positive verification of the hypothesis, showing the lower resilience in sectors where personal contact is required and there are no online-service possibilities. In these sectors the financial buffer is relevant in terms of economic resilience. Mostly the presented research results are coherent with the results of the hitherto published studies on the impacts of the Covid-19 pandemic on the financial standing of enterprise [11][18][32]. However the authors unlike cited other research focused on whole group of small companies hence the results are not 
general but focused on resilience of small companies. Due to the still ongoing pandemic and multidimensionality of the described issues it is not yet possible to provide both unambiguous and complex evaluation. Most of the studies quoted in this paper are of a similar, fragmentary nature [18][12][13]. Nevertheless, the novelty of our research is not only sector approach but as well the orientation on chosen group of entities (small enterprises) and the application of the chosen indicators, which in the authors' opinion are the most appropriated for short-term effect. Without any doubts the pandemic situation is unprecedented and hardly comparable to previous crises studies. Hence it was essential to check the small enterprises financial reaction on it. The focus on four main financial areas: liquidity, sales, revenues and profit allow to assess the early reaction on pandemic

The research results presented in this paper have shown a considerable sectoral diversity of responses to the first lockdown. Hence, the authors recommend government and not-government support should apply different measures to each sector. The financial result as well profitability levels are the indicators that have deteriorated in the greatest number of sectors, what implies support in this area. Financial liquidity, however, turned out to be the most stable indicator. Information about deterioration of indicators in particular sectors may be helpful in targeting governmental financial support. Until now, government aid has been directed generally to enterprises without detailed distinction, but it would be worthwhile to target specific goals, including restructuring. Therefore, the analysis of immediate effects is needed as well in order to cope with the longer-term challenges. As Juergensen et al. indicated, policy interventions should be sensitive to the different types of SMEs, rather than adopting a one-size-fits-all approach [13], hence knowing the sectoral problems and needs is a key issue.

Our research is not free from limitations that we acknowledge. The research was highly dependent on access to data, as we were interested to find out whether some downturn symptoms were visible as early as in the first months of the pandemic. The authors' intention is to continue the research in a longer perspective. A two- or three-year perspective would make it possible to provide a multidimensional evaluation of not only the financial security, but also issues connected with enterprises profitability. Our findings can have implications in further, deeper studies on immunity and vulnerability of small enterprises to the COVID-19 crisis.

\section{References:}

[1] OECD, The territorial impact of COVID-19: Managing the crisis across levels of government, June 2020. Available online: http://www.oecd.org/coronavirus/policyresponses/the-territorial-impact-of-COVID19-managing-the-crisis-across-levels-ofgovernment-d3e314e1/ (Accessed on 10 November 2020)

[2] Shapiro, A. H., Monitoring the Inflationary Effects of COVID-19, FRBSF Economic Letter, Federal Reserve Bank of San Francisco, vol. 2020 (24), p. 1-6.

[3] Drechsel, T.; Kalemli-Özcan, S., Are standard macro and credit policies enough to deal with the economic fallout from a global pandemic? A proposal for a negative SME tax, March 2020. mimeo University of Maryland

[4] Coibion, O.; Gorodnichenko, Y.; Weber, M., Labor markets during the covid-19 crisis: A preliminary view, NBER Working Paper 27017, April 2020, DOI 10.3386/w27017.

[5] Guerini, M.; Nesta, L.; Ragot, X.; Schiavo, S., Firm liquidity and solvency under the Covid-19 lockdown in France, OFCE Policy Brief, July 2020, (76).

[6] Ebeke, C.; Jovanovic, N.; Valderrama, L.; Zhou, J., Corporate Liquidity and Solvency in Europe during COVID-19: The Role of Policies, IMF Working Paper WP/21/56, 2021.

[7] Core, F.; De Marco, F., Public Guarantees for Small Businesses in Italy during COVID-19, CEPR Discussion Paper No. DP15799, 2021.

[8] Dai, R.; Feng, H.; Hu, J.; Jin, Q.; Li, H; Wang, R.; Xu, L.; Zhang, X., The impact of COVID-19 on small and medium-sized enterprises (SMEs): Evidence from twowave phone surveys in China, Cina Economic Review, Volume 67, June 2021.

[9] Cepel, M.; Gavurova, B.; Dvorsky, J.; Belas, J., The impact of the COVID-19 crisis on the perception of business risk in the SME segment, Journal of International Studies, 13(3), p. 248-263. doi:10.14254/2071-8330.2020/13-3/16

[10] Kaczmarek, T.; Perez, K.; Demir, E.; Zaremba, A., How to survive a pandemic: The corporate resiliency of travel and leisure companies to the COVID-19 
outbreak, Tourism Management 84 (2021), https://doi.org/10.1016/j.tourman.2020.1042 81

[11]Kuckertz, A.; Brändle, L.; Gaudig, A.; Hinderer, S.; Morales-Reyes, A.M.; Prochotta, A.; Steinbrink, K.M.; Berger, E.S.C.,Startups in times of crisis - a rapid response to the COVID-19 pandemic, Journal of Business Venturing Insights, 13 (2020), pp. 1-13.

[12] Humphries, J.E.; Neilson, C.; Ulyssea, G., The evolving impacts of COVID-19 on small business since the CARES Act, Cowles Foundation Discussion Paper No. 2230, 2020.

[13] Juergensen, J.; Guimób, J.; Narula, R., European SMEs amidst the COVID-19 crisis: assessing impact and policy responses, Journal of Industrial and Business Economics, 47, 2020, p.499-510.

[14] Kawaguchi, K.; Kodama, N.; Tanaka, M., Small Business under the COVID-19 Crisis. Expected Short- and Medium-Run Effects of Anti-Contagion and Economic Policies, September $\quad 10, \quad 2020$, http://dx.doi.org/10.2139/ssrn.3634544

[15] Delas, V.; Nosova, E.; Yafinovych, O., Financial Security of Enterprises, Procedia Economics and Finance, Vol. 27, 2015.

[16] Adian, I.; Doumbia, D.; Gregory, N.; Ragoussis, A.; Reddy, A.; Timmis, J., Small and Medium Enterprises in the Pandemic: Impact, Responses and the Role of Development Finance, Policy Research Working Paper;No. 9414. World Bank, Washington, DC, 2020.

[17] Barasa E., Mbau R. \& Gilson L. (2018), What is resilience and how can it be nurtured? A systematic review of empirical literature on organizational resilience, International Journal of Health Policy and Management 7(6), pp. 491-503. doi:10.15171/ijhpm.2018.06

[18] Bartik, A.W.; Bertrand, M.; Cullen, Z.B.; Glaeser, E.L.; Luca, M.; Stanton, C.T., How Are Small Businesses Adjusting to COVID19? Early Evidence from a Survey, NBER Working Paper No. 26989, 2020.

[19] Vogus T.J. and Sutcliffe K.M. (2007), Organizational resilience: towards a theory and research agenda. Paper presented at: ISIC. IEEE International Conference. doi:10.1109/ ICSMC.2007.4414160

[20] Holling C.S. (1973), Resilience and stability of ecological systems. Annual Review of
Ecology and Systematic 4:1-23. doi:10.1146/annurev.es.04.110173.000245

[21] Herrfahrdt-Pähle E. and Pahl-Wostl C. (2012), Continuity and Change in Socialecological Systems: the Role of Institutional Resilience. Ecology and Society; 17(2):8. doi:10.5751/ES-04565-170208

[22] Kieny M.P., Evans D.B., Schmets G. and Kadandale S. (2014), Health-system resilience: reflections on the Ebola crisis in western Africa. Bulletin of the World Health Organization; 92(12):850. doi:10.2471/ blt.14.149278

[23] Kruk M.E., Ling E.J., Bitton A. et al. (2017), Building resilient health systems: a proposal for a resilience index. BMJ 23;357:j2323. doi:10.1136/bmj.j2323

[24] Somers S. (2009), Measuring Resilience Potential: An Adaptive Strategy for Organizational Crisis Planning, Journal of Contingencies and Crisis Management, Volume 17, issue 1, pp. 12-23. https://doi.org/10.1111/j.14685973.2009.00558.x

[25] Kayes D. C. (2015), Organizational Resilience: How Learning Sustains Organizations in Crisis, Disaster, and Breakdown. Oxford University Press. Doi:10.1093/acprof:oso/9780199791057.00 1.0001

[26] Skouloudis A., Tsalis T., Nikolaou I., Evangelinos K. and Filho W.L. (2020), Small \& Medium-Sized Enterprises, Organization Resilience Capacity and Flash Floods: Insights from a Literature Review, Sustainability $2020, \quad 12, \quad 7437$; doi:10.3390/su12187437

[27] Fiksel J. (2015), Resilient by Design: Creating Businesses That Adapt and Flourish in a Changing World, Island Press.

[28] Tierney K. (2003), Conceptualizing and Measuring Organizational and Community Resilience: Lessons from the Emergency Response Following the September 11, 2001 Attack on the World Trade Center. Preliminary paper 329. University of Delaware, Disaster Research Center, Newark.

[29] McManus S., Seville E., Brunsdon D. and Vargo J. (2007), Resilience Management: A Framework for Assessing and Improving the Resilience of Organisations. Resilient Organisations Research Report 2007/01.

[30] Pal R., Torstensson H. and Mattila H. (2014), Antecedents of organizational 
resilience in economic crises - an empirical study of Swedish textile and clothing SMEs. International Journal of Production Economics vol. 147, pp, 410-428. doi:10.1016/j.ijpe.2013.02.031

[31] Zhong M. (2021), Research on the organizational resilience construction of SMEs under the background of VUCA, 2021 International Conference on Electronic Commerce, Engineering Management and Information Systems, Francis Academic Press UK, pp. 438-443. doi: 10.25236/ecemis.2021.077

[32] Gourinchas, P.O.; Kalemli-Özcan, S.; Penciakova, V.; Sander, N., Covid-19 and SME Failures, IMF Working Paper WP/20/207, 2020.

[33] McGuiness, G.; Hogan, T., Bank credit and trade credit: Evidence from SMEs over the financial crisis, International Small Business Journal, Vol 34, Issue 4, 2016, p. 412-445.

[34] Bourletidis, K.; Triantafyllopoulos, Y., SMEs Survival in time of Crisis: Strategies, Tactics and Commercial Success Strories, Procedia - Social and Behavioral Sciences 148, 2014, p.639-644.

[35] Yildirim, D.C.; Tosuner Unal, O.; Gedikli, A., Financial Problems of Small and Medium-Sized Enterprises in Turkey, International Journal of Academic Research in Business and Social Sciences, January 2015, Vol. 5, No. 1.

[36] Sullivan-Taylor B. and Branicki, L. (2011), Creating resilient SMEs: why one size might not fit all, International Journal of Production Research, 49(18):5565-5579, doi:10.1080/00207543.2011.563837

[37] Marković M.R., Farooq M.S. and Marković D. (2017), Strengthening the Resilience of Small and Medium-Sized Enterprises, Management, Enterprise and Benchmarking in the 21st Century, pp. 345-356.

[38] Klein V.B. and Todesco J.L. (2021), COVID-19 crisis and SMEs responses: The role of digital transformation, Knowledge and Process Management, https://doi.org/10.1002/kpm.1660

[39] Fu X. (2020), Research on the Survival Strategy of SMEs under COVID-19--Based on the Perspective of Organizational Resilience, Advances in Economics, Business and Management Research, vol. 159, pp. 603-606.
[40] Franc-Dąbrowska, J., Bezpieczeństwo finansowe a efektywność zaangażowania kapitałów własnych, Roczniki Nauk Rolniczych, SERIA G, t. 93, z.1, 2006.

[41] Karbownik, L., Kasowe i memoriałowe mierniki oceny bezpieczeństwa finansowego przedsiębiorstw, Acta Universitatis Lodziensis, Folia Oeconomica 267/2012, 2012.

[42] Raczkowski, K., Bezpieczeństwo finansowe, [w:] Płaczek, J. (red.), Ekonomika bezpieczeństwa państwa w zarysie, Difin, Warszawa 2014.

[43] Szafraniec-Siluta, E., Bezpieczeństwo finansowe przedsiębiorstw rolniczych $w$ Polsce - ujęcie porównawcze, Zarządzanie i Finanse r.11, nr 2, cz.2, 2013.

[44] Blakyta, G.; Ganushchak, T., Enterprise financial security as a component of the economic security of the state, Investment Management and Financial Innovations, 15(2), p. 248-256, 2018. Doi:10.21511/imfi.15(2).2018.22

[45] Rushchyshyn N.; Nikonenko, U.; Kostak, Z., Formation of financial security of the enterprise based on strategic planning, Baltic Journal of Economic Studies, Vol. 3, No. 4, 2017.

[46] Karels, G.V.; Prakash, A.J., Multivariate Normality and Forecasting of Business Bankruptcy, Journal of Businsess Finance and Accounting, Vol 14, Issue 4, 1987, pp. 573-592.

[47] Laitinen, T., Financial ratios and different failure processes, Journal of Business Finance and Accounting, Volume 18, Issue 5,1991, p. 649-673.

[48] Garcia, W.C.; Ho, V., What types of firms become illiquid as a result of COVID-19? A firm-level perspective using French data, European Commission, Discussion paper 136, January 2021, doi:10.2765/73924.

[49] Liu, X., Impacts of the Global Financial Crisis on Small and Medium Enterprises in the People's Republic of China, ADBI Working Paper 180, Asian Development Bank Institute, Tokyo, 2009. Available online: http://www.adbi.org/workingpaper/2009/12/16/3421.impacts.gfc.enterpri ses.prc/ (Accessed on 10 April 2020)

[50] Soininen, J.; Puumalainen, K.; Sjögrén, H.; Syrjä, P., The impact of global economic crisis on SMEs: Does entrepreneurial orientation matter?, Management Research 
Review 35, 2012, p. 927-944, DOI: 10.1108/01409171211272660.

[51] Sierpińska, M.; Jachna, T., Ocena przedsiębiorstwa według standardów światowych, Wydawnictwo Naukowe PWN, Warszawa 2004.

[52] Skowronek-Mielczarek, A.; Leszczyński, Z., Analiza działalności i rozwoju przedsiębiorstwa, PWE, Warszawa 2008.

[53] Mosiejko, L.; Bernardelli, M.; Sierant, A., Płynność finansowa spółek notowanych na Giełdzie Papierów Wartościowych w Warszawie SA w latach 2002-2017 w ujęciu sektorowym - część 1, Studia i Prace, Kolegium Zarządzania i Finansów, 173/2019, p. 9-27.

[54] Sharma, S.; Mahajan. V., Early Warning Indicators of Business Failure, Journal of Marketing, Fall 1980, pp. 80-89.

[55] Przewodnik Antykryzysowy dla Przedsiębiorców, Polski Fundusz Rozwoju, 2020

[56] Guias F, Effects of the Reproduction Number in a SEIIRD Model Describing the Time Evolution of COVID-19 at Country Level, WSEAS Transactions on Computers, Volume 19, 2020, pp. 292-297.

[57] Asad, A., Srivastava, S., Verma, M.K. Evolution of COVID-19 Pandemic in India.Trans Indian Natl. Acad. Eng. 5, 711-718 (2020). https://doi.org/10.1007/s41403-020-00166-y

[58] Skegg D., Gluckman P., Boulton G., Hackmann H., Karim S.S.A., Piot P.,Woopen C., Future scenarios for the COVID-19 pandemic, The Lancet, Volume 397, issue 10276, P777-778, 2021.

[59] Chua C., Ruzgar N.S., Perceptions of Business Students toward Online Education before and in Transition Period of COVID19, WSEAS Transactions on Computers, Volume 19, 2020, pp. 242-261.

[60] Męcina, J., Finansowanie Tarczy Antykryzysowej - ocena sytuacji gospodarczej firm i postulaty, Open Eyes Economy Summit, Raport 21, 2020.

[61] Praktyczny przewodnik po instrumentach wsparcia i rozwiązaniach antykryzysowych, CRIDO, 2020.

[62] Dimson, J.; Mladenov, Z.; Sharma, R.; Tadjeddine, K., COVID-19 and European small and medium-size entreprises: How they are weathering the storm, McKinsey and Company, 2020.

[63] Thorgren, S.; Williams, T.A., Staying alive during an unfolding crisis: How SMEs ward off impending disaster, Journal of Business Venturing Insights, Volume 14, e000187, 2020.

[64] Baños-Caballero, S.; García-Teruel, P.J.; Martínez-Solano, P., Financing of working capital requirement, financial flexibility and SME performance, Journal of Business Economics and Management, 17:6, 2016, pp. 1189-1204, DOI:10.3846/16111699.2015.1081272

[65] Cassim, Z.; Handjiski, B.; Schubert, J.; Zouaoui, Y., The $\$ 10$ trillion rescue: How governments can deliver impact, McKinsey and Company, 2020.

[66] OECD, Tackling Coronavirus (COVID-19): Contributing to a Global Effort, 2020. Available online: http://www.oecd.org/coronavirus/en/ (Accessed on 5 November 2020).

\section{Contribution of Individual Authors to the Creation of a Scientific Article (Ghostwriting Policy) \\ Author Contributions:}

Dominika Kordela: conceptualization, methodology, resources, formal analysis.

Monika Pettersen-Sobczyk: conceptualization, methodology, resources, conclusions.

\section{Sources of funding for research presented in a scientific article or scientific article itself}

The project is financed within the framework of the program of the Minister of Science and Higher Education under the name "Regional Excellence Initiative" in the years 2019 - 2022; project number 001/RID/2018/19; the amount of financing PLN $10,684,000.00$.

Creative Commons Attribution License 4.0 (Attribution 4.0 International, CC BY 4.0)

This article is published under the terms of the Creative Commons Attribution License 4.0 https://creativecommons.org/licenses/by/4.0/deed.en US 